\title{
An Invitation to the Ethnographic Study of University Examination Behavior: Concepts, Methodology, and Implications
}

\section{CHERYL ALBAS \& DAN ALBAS}

University of Manitoba

\section{Abstract}

The topic of this paper is student life as it relates to examinations. There are two foci: first, the field of higher education and, second, qualitative methodology and theoretical implications for higher education, particularly with regard to dealing with exam-related stress in students. Data collection involved interviews, observation, 'Garfinkling,' and unobtrusive measures. The data analysis and theoretical implications are from our earlier previously published studies. They include student 'magic,' emotion work, impression management and examination dramaturgy. Brief synopses of these studies are included to provide clear relevance of the discussion.

The authors thank D.L. Rennie for his contribution. Thanks also to A.D. Gregor, A. Boberg, and the reviewers for their helpful comments on earlier drafts of this work. 


\section{Résumé}

Cet article qui aborde la question des examens sous l'angle de la vie des étudiants, met l'accent sur deux points principaux: premièrement, le domaine de l'enseignement supérieur, et deuxièmement, la méthodologie qualitative et ses implications théoriques par rapport à l'enseignement supérieur, particulièrement en ce qui concerne la façon dont les étudiants gèrent le stress associé aux examens. Les données ont été recueillies au moyen d'interviews, de l'observation, notamment en contexte ouverte ( «Garfinkling») et d'autres méthodes non intrusives. L'analyse des données et les implications théoriques proviennent d'études déjà publiées par les auteurs. Elles comprennent entre autres les «crituels magiques» des examens, la maîtrise des émotions, la gestion des impressions et la dramaturge des examens. De brefs résumés de ces études sont présentés dans le but de démontrer la pertinence de l'analyse ethnographique par rapport à l'enseignement supérieur.

Leading scholars in the field of higher education are calling for more qualitative research (Huberman \& Miles, 1983; Kuh \& Andreas, 1991). A review of the literature in the area of higher education reveals a dearth of studies of a qualitative nature dealing with examinations. Such studies as exist are mainly quantitative and deal largely with topics like social class and social performance (Bajema, 1968; Sexton, 1961). Where this literature touches upon examinations, it does so more from the standpoint of examinations as functional for accreditation for social roles (manifest) and maintenance of the established stratification system (latent) (Giddens, 1973; Pascarella \& Terenzini, 1991; Weber, 1968, p. 1000). It does not deal with the everyday dynamics of preparing for and writing examinations from the standpoint of the students themselves. This paper is offered in the hope of inviting interest and perhaps company in researching the area. The study of the examination is important because it is the culmination of an instructional process and is also an evaluation of the process itself as well as of the candidate who is to be presented to society as, it is hoped, a polished product (Broadfoot, 1984; Tepperman \& Curtis, 1995, p. 217).

As the title indicates in this paper an attempt is made to demonstrate the qualitative methodology employed over the years in our ethnographic 
study of university student life as it relates to examinations. The paper has two distinct foci: first, the message is clearly one related to the field of higher education and second, it is explicitly a demonstration of the use of qualitative methodology. The first part of the paper deals with various techniques of data gathering, and then discusses the inextricable linkage of methodology and theory. Then, using already published studies (Albas \& Albas, 1984, 1988a, 1988b, 1989a, 1989b, 1993, 1995, 1996; Albas \& Albas, 1988) we demonstrate how we made theoretical sense of the data obtained as described in the first section of the paper. In carrying out these objectives, we attempt to lead readers through our thought processes as our empirical findings are submitted to examination in the light of existing theories. This is what Burgess (1984, p. 160) suggests is widely lacking in current research reporting. These theories are then used to direct the collection of further, more focused data upon the basis of which existing theories are modified and occasionally new ones are suggested. A secondary function of the paper is to elucidate theoretically the underlying motivations of students and their reactions to stress. If these are fully understood, more functional and effective procedures for dealing with them can be developed by educators. We hope the paper will make some contributions to such understandings. Specific, more detailed implications are offered in the final section.

\section{Getting Access To and Collection of Data}

The requisite of any research project is to gain access to a setting from which data may be obtained and to subjects who can supply these data (Shaffir, Stebbins \& Turowetz, 1981). In our case, access to the research setting could be said to come naturally in that the setting is the university classroom and we are faculty members. The university in question is located in a large midwestern Canadian city and has approximately 24,000 students. It offers a wide variety of undergraduate, graduate and professional programs. In regard to the subjects (mostly students), though indeed we have access to them as informants we nevertheless observe scrupulously the ethics relevant to the issue of human subjects in research, i.e., confidentiality, refraining from undue pressure or any 
semblance of coercion. In addition to data obtained from student subjects we also obtained data by observation, interviews, 'Garfinkling,' and unobtrusive measures. These procedures are detailed below.

\section{Observation}

When a researcher observes social action taking place, the observation may be carried out while participating with the subjects being observed while carrying out the activities in which they are engaged. In this method, referred to as participant observation, subjects may or may not be aware that there is an observer-researcher in their midst. Such an approach is especially useful for getting an 'inside' view of the situation (Yin, 1994, p. 88). Observation, Adler and Adler (1994, p. 38) indicate, is especially "well suited to the dramaturgical perspective because it enables researchers to capture the range of facts, from the minimovements to the grand gestures, of people under study." Observation may also be carried out by an observer who does not participate in the action (for example, observation from behind a one-way viewing screen). In our research we employed all three of these approaches to observing student life, particularly at exam time. To be more specific: although we made it known to students that we were studying student life and that one method of gathering data would be by observing them, they might not always have been conscious of our roles as observer and researcher while we were at the same time engaged in the professional role of instructor or invigilator. There were, of course, times when they did realize this, particularly when they were asked to come for interviews following particular things we had observed. This factor dealt with at greater length in the discussion on interviewing. In regard to observations made by us as non-participants in the action, these were situations in which we did our own reading, grading, (and of course observing) in close proximity to student carrels and tables in the library. As far as they were concerned, we were merely reading or grading. For all they knew we could have been mature students. Of course, this closed awareness context, as Glazer and Strauss (1981) call it, could only take place when we observed students other than our own (e.g., one from other faculties on this campus or from the other university in the city). 
In a somewhat larger focus, we had professionally-taken photographs of students writing examinations - hundreds of students in straight lines and rows in examination halls and classrooms. From these photographs we observed positions assumed as to the arrangement of legs, use of the hands (e.g., to cover their papers), directions of the eyes, and tilt of the body with respect to neighbors, etc. The study of these photographs often provided us with particular positions and gestures to look out for during actual examinations and to pursue as to meanings. In addition to our observations we also made use of the observations related to us by our teaching assistant invigilators. We attempted to select teaching assistants for this function who had a minimum, if any, experience in the role of invigilator. In this way we obtained the unique focus that could be called 'stranger value' (Burgess, 1984, p. 23). It was interesting to note that after these tyro invigilators became more blasé about their role, they also became (perhaps like ourselves) less perceptive of subtle nuances. In addition, we also solicited from exam invigilators in other disciplines and faculties their observations of examination behaviors.

All of these observations by ourselves and others had to be recorded, sometimes on the spot (if this could be done unobtrusively) and always after in as much detail and exactness as possible. Prolific note-taking resulted in the accumulation of a veritable mountain of recorded observations which had to be sorted through for relevance and sense-making. The material suggested, by the particular relevance of its various facets, a number of different theoretical approaches to understanding it (e.g., magic, impression management, emotion work, etc.). Accordingly, in the later phases of the data collection process we began to be less omnivorous and to focus upon these specific theoretical areas. This procedure referred to by Strauss and Corbin (1990) as theoretical sampling is more typical of ethnographic methodology than of more formal mathematical quantitative approaches. Throughout this process of observation (participant, non-participant, use of photographs, and use of assistants) every attempt was made to avoid a Hawthorne effect (i.e., allowing our procedures to affect the behavior of the subjects being studied). This we did by making notes as inconspicuously as possible and when we did have to make notes in front of people, we jotted down only the minimum 
necessary. Whenever possible, note-taking was confined to the back of the room where we could not be observed by the students writing their exams. Even obvious close observation of students need not necessarily be interpreted by them as information gathering about them because it is the natural role of the invigilator, just as scribbling in a library is what one does naturally. There were occasions though in which it was inevitable that we "blew our cover" and thus did affect the interaction under investigation. For example, on occasion we were observed taking notes and students interpreted our behavior as gathering information to build a case against cheaters. This undoubtedly produced in our subjects a more than normally assiduous scrupulousness.

In addition, we also engaged in a variety of other research techniques because as Alder and Alder (1994, p. 382) state observation produces "especially great rigor when combined with other methods."

\section{Interviewing}

Over the years a considerable amount of data was collected by interviewing students, faculty members, and members of the university administration. Most of these interviews were informal, spontaneous, on the spot episodes when we casually asked students to explain some strange behavior. For example, one student accidently kicked over a pile of books and notes piled on the floor under his desk. As he reached down with his hands to reorder the pile, he suddenly realized he was being observed by an invigilator. In mid reach he froze and proceeded to attempt to rearrange the pile, this time with his feet. When asked why he behaved in this matter. He replied "guilt based on a smoking gun is more credible if the gun is in the hand rather than in the foot." In asking onthe-spot questions we tried, in the spirit of Howard Becker (1958) to "time, shape and minimize [our] provocations in order to induce [our respondents] to express themselves with a 'natural' sense of their familiar situations" (Katz 1994, p. 272). However, we also carried out other interviews that were longer, more formal and in some instances, taped . Virtually all of the interviewing, formal and informal, revolved around questions emerging from our observations. In this way we were able to minimize or at least explain discrepancies between verbal claims made 
by subjects and their actual behavior (Becker \& Geer, 1957). In some cases interviews changed our perspective on the scenes we were observing and alerted us to look out for aspects we had previously overlooked.

\section{Garfinkling}

This term implies an ethnomethodological manipulation of a situation in which the conventional pattern of interaction is made problematic or troublesome in order "to demonstrate what societal members commonly assume or do that prevents such "troubles" (Cahill et al., 1995, p. 612). At the very least, a researcher can elicit from the intensity of reaction to the breach, the degree of importance the subject attached to the rule that is violated (Garfinkel, 1967). For example, we were aware that there exists in student culture a norm of courtesy and face-saving for others. Accordingly, we employed a stooge, who to all appearances was one of the less able students referred to (among ourselves) as Bombers, to join a group of other Bombers commiserating with each other at a pity-party over their recent examination debacle. In response to cries of indignation at the stupidity of the professor, the impossibility of the exam, and the general bleakness of life, the stooge was instructed to say, "For anyone who did the least bit of studying, the exam was a piece of cake." As predicted, the response was one of scandalized horror and indignation. The stooge was also instructed (in mercy) to add immediately after "Of course, I'm kidding." However, we clearly established the existence of the norm which was the point of the experiment. Although we made use of a number of such contrived episodes, we always attempted to avoid lasting harm to the subjects.

\section{Unobtrusive Measures}

In all three approaches described above, there is inevitably some possibility of observer effect on the subjects observed, interviewed or manipulated. To compensate for this Hawthorne effect we made use of unobtrusive measures (Webb et al., 1966). The distinct advantage of this procedure over surveys (which record merely what people say) has been elaborated by Deutcher (1973) and Becker and Geer (1957). This fourth approach involves contact, not with subjects themselves, but with 
'traces' left by them. These traces are physical items left behind by people that are connected to their goals and as such tell us something about them. Because these traces are left behind without the producers' knowledge of their potential usefulness to researchers, they are clearly not affected by research influence. For example, to measure frequency of library and study space usage we used turnstyle counts in the library and items left behind in a study room. One measure of exam fever was the prevalence of graffiti and messages on notice boards left by students reminding each other of the approaching Armageddon. Such physical artifacts added context and thickness to the descriptive report.

\section{Student Logs}

Lastly, the most explicit and significant data sources employed but which we cannot claim to be completely free of observer effect, are the logs or detailed accounts which students wrote for us describing their life experience with particular regard to examinations. These logs, as Cahill, et al. (1995, p. 610) indicate, can "compensate for gaps in the direct experience of subjects' everyday lives." These accounts provided for us what the letters and diaries of Polish peasants provided for Thomas and Zhaniecki (1919). The assignment was intentionally nondirective except for its focus on examinations. However, we did employ a number of techniques to check whether accounts were spurious and written so as to please us, for example, when a log was handed in we asked students what effect the writing of it had on them. Many expressed relief at facing issues involved for the first time and getting it off their chests. Many of the accounts were self-deprecatory and could hardly have been attempts to over-represent themselves in the best light. Students were reminded at the outset of the scientific importance of what we were asking them to do and warned that we were able to discern fraud which would merely waste our time and theirs. We used as typical examples only those that appeared repeatedly in the logs and represented the experiences of a significant number of the students. 


\section{Data Analysis and Interpretations}

In science, methodology and theory are inseparable if useful and valid understandings are to be achieved concerning any subject of inquiry. Indeed, the term inquiry itself implies the asking of questions. The type of questions asked about a phenomenon, usually at an abstract, general level (i.e., the paradigm or frame of reference) and the tentative, suggested answers (i.e., hypotheses) constitute the theoretical component of the enterprise to understand the what, why, and how of the phenomenon. The methodological component consists of 1) generating the empirical data validity germane to the paradigm (e.g., operationalized forms of the questions and their answers on the basis of observations, interviews, official documents, etc.) and 2) analysis of these data to determine whether the tentative answers (hypotheses) do indeed conform to the empirical findings. Either component without the other is virtually useless because, as Merton (1957) states, they both play back upon each other to their mutual refinement, clarification, and precision. To regard theory and method as dichotomous is spurious.

As was noted earlier, our data collection procedures involved a number of sources. These multi-source data were brought together in the same way that photographs may be taken from a number of different angles and in different conditions of light. In this way, a given approach with inherent weaknesses (such as the subjectivity of the student logs) is, it is hoped, corrected for by the objective strength of another approach (for example, the use of traces). Both logs and traces are further validated or corrected by the data from interviews and observations. Thus, in this paper although the emphasis is on the methodological component of ethnographic research, the procedural techniques will, of necessity, be described with reference to established theoretical orientations and assumptions.

\section{Examples From Selected Studies}

\section{Student Magic for Exam Success}

We observed that, particularly at exam time, students display nonrational and bizarre behavior in an astounding array of seemingly inexplicable and often contradictory practices which seem very much like magic 
(Albas \& Albas, 1989a). Yet it is the late twentieth century and the setting is one where one might expect maximum rationality and so this can hardly be magic in the commonly accepted sense. Our definition of magic in this context was "action directed toward the achievement of a particular outcome with no logical relationship between the action and the outcome or, indeed, any empirical evidence that one produces the other." The majority of these practices categorized as magic also had a 'mystical' component. For example, if a subject reported that she studied for exams in the same classroom where she had her lectures because of the efficacy of familiar cues in stimulating memory, it was not included as an example of magic. However, if the reason given for studying in the classroom was that there remained in it all the bits of knowledge taught for the term "still swirling around to be caught again" that response was included as an example of magic. When we wrote a representative sample of such practices on a large chalkboard, we found that it was possible to classify them into two major categories - "Do's" -for luck and "Don'ts" -to avoid bad luck (i.e., taboos about what should be scrupulously avoided and what should be religiously conformed to at exam time). Furthermore, within each of the two major categories we found consistent sub-patterns such as the wearing of "Oldies and Oddies" (the sweatshirt of a brilliant boyfriend or the ring of a scholarly mother); and the performance of symbolic rituals (e.g., breakfasting on one slice of bacon placed vertically on the plate and two eggs, sunnyside up beside it imaging $100 \%$ ). In this way the what of student magic was able to be conspicuously documented. Discerning the why was what brought theory to bear on the matter in order to make sociological sense of (superficially) seemingly senseless behavior. We knew that Malinowski (1954) attributed the magic practiced by Trobriand Islanders to the anxiety they experienced when they fished in the dangerous waters beyond the lagoon. We also knew that miners (Wilson, 1942), actors, athletes (Gmelch, 1971), and soldiers (Stouffer, et al., 1949) used totems of one kind or another to protect them and bring them success. All of these are high-anxiety activities. It was therefore feasible to think that the Malinowski hypothesis of magic as a stress-coping mechanism is supported in the cases of miners, actors, athletes, and pilots. We then 
returned to our own data for evidence of how students said that they felt after a pet dog "had waved a paw" and woofed "good luck" before an exam, or after eating a carrot muffin purchased from a specific vendor, the Patty Wagon. In all cases, the feelings experienced were relief as well as belief that without the woof or the muffin the exam outcome would have been problematic. At this point we accepted the hypothesis that student 'magic' is indeed a stress-coping mechanism.

However, our investigation did not stop there. For the sake of theoretical integration we attempted to establish where in the hierarchy of magic 'student magic' sits and why it might differ from the magic of preliterate people. From the literature we constructed an ideal type polar construct of the characteristics of magic with preliterate society at one pole and contemporary society at the other as seen in Table 1. After examining hundreds of reports from students, we decided that student magic falls at the right end of all four continua. We hope that in making this explicit somewhat of a contribution may have been made to the theoretical understanding of student life.

In sum, in the study of student magic just described, our procedure was to begin with the raw data (namely the What of student magical practices), and then to classify these practices and look for patterns. From these patterns, and guided by existing theoretical literature, we were able to establish the Why of the practices as being consistent with

Table 1

Magical practice in preliterate to contemporary societies: A continuum Characteristic Practice Society

\begin{tabular}{|c|c|c|}
\hline & Preliterate & Contemporary \\
\hline Performance & Public - & $\rightarrow$ Private \\
\hline Transmission/Generation & Cultural - & $\rightarrow$ Spontaneous \\
\hline Community Involvement & Shared & $\rightarrow$ Private \\
\hline Rubric & Fixed & $\rightarrow$ Varying \\
\hline
\end{tabular}


those in several other areas of life where stress, uncertainty, and anxiety exist. Finally, we distinguished along the four continua where these student practices we call magic fall relative to and are different from other forms of magic.

\section{Emotion Work at Exam Time}

In the second study of students experiencing stress at examination time (Albas \& Albas, 1988) we began with three formal hypotheses derived from Arlie Hochschild's (1979) theories regarding 'feeling rules' and 'emotion work' done by people under stress to contain their feelings within the parameters defined by the rules. The hypotheses were: 1) rules exist in the student culture defining the appropriate level of emotional intensity at examination time; 2) because we think most students' level will exceed the defined norm, the direction of emotion work will be in a suppressing direction; and 3) the duration of emotion work done will coincide with the examination period.

The methodology in this study is a good example of the procedure used extensively in most of our studies of student life, namely triangulation in which data of different kinds were collected from a variety of sources. Also, under this rubic of triangulation, we used photographs of examinations in progress as a projective technique to elicit from students their empathy with 'other suffering souls' and their insights into explanations of the postures and facial expressions in the photographs.

On the basis of this body of mainly qualitative data we were able to document that during the examination period students attempt to keep their feelings within an optimum range by engaging in intense emotion work of a dampening kind, for example, listening to music, jogging, or avoiding talk about the exam. In addition, we documented the variety of forms that emotion work takes - physical (e.g., compulsive cleaning and tidying of rooms), cognitive (e.g., establishing a hierarchy of preparation procedures), spiritual (e.g., praying), and affiliation (e.g., seeking the company of others who are in the 'same boat'). Doing emotion work to pump up or repress levels of emotion to a desired optimum is widespread in all aspects of everyday life and is especially apparent among athletes at competition time. 


\section{Impression Management by Types of Students}

In the third paper (Albas \& Albas, 1988a) we focused on impression management, and important aspect of dramaturgy. Specifically, we recognized that the examination is an arena of prolific impression management by students to protect and enhance a positive view of themselves. Accordingly, using all the sources of data-gathering referred to earlier, we collected a large number of cases in which bright students (Aces) and weaker students (Bombers) either revealed or concealed their grades and their feelings about their grades after examinations. Once again, the first task was to classify the complex and, in places, contradictory student accounts, our observations and interviews, and then to search for patterns. Eventually we were able to identify seven patterns of revelation and five of concealment. Examples of patterns of revelation used by Aces were 1) 'repressed bubbling' wherein satisfaction is made to appear as if it was seeping out of them against their will, in effect, excitement is repressed by an obvious modesty; and 2) 'accidental revelation' where students accidently leave their exam papers, face up with grades obviously visible, on the edge of the desk for a decently discrete period of time. Examples of patterns of concealment were 1) 'emphatic concealment' in which Bombers assumed a rigid posture, angled their shoulders away from the people they were sitting beside, and riveted their eyes on their papers in a concentrated study of them that precluded any interruption, such as being asked "How much did you get?"; and 2) 'subtle concealment' which they rapidly and accidently lose the test paper in a shuffle of books and other papers.

In addition to the revelation of grades by Aces and the concealment of them by Bombers, we also documented a patterned impression management drama when students who received back their examination papers sought out, casually met, or tried to avoid meeting each other. These encounters fall into four categories: Ace-Ace, Ace-Bomber, Bomber-Ace, and Bomber-Bomber. The Ace-Ace encounters often involve a little bragging, a critical review of each of the questions on the exam, and of the tactics used in answering them. There is almost a complete absence of impression management. Ace-Bomber encounters are characterized by considerable impression management, especially on the 
part of Aces and especially when they sense how poorly a particular Bomber has done. One Ace, who in his own group was heard to remark that the exam was a piece of cake, now guided by the norm of face-saving remarked to a Bomber now how difficult it was. In addition, the Ace said he knew it was especially difficult for the Bomber because he had little time to study for it. Bomber-Bomber encounters are, for the most part, 'pity parties' in which the discussion takes the form of excuses. Once again, the norm is one of face-saving and courtesy. Bombers try to build each other up with encouraging remarks. For example, one said to the other "don't feel badly, you know you are actually very intelligent" to which comment a second friend present vigorously nodded her head in agreement. All of these types of encounters clearly illustrate what Fine and Kleinman (1979) refer to as "group culture, anchored in their situationally relevant identity."

It is now possible to answer the second question posed by the study concerning the intensity or absence of impression management. That is, expressions of impression management will be intensified when there exists a clash between the struggle for achievement or ascendency on the one hand, and a strain for rapport and congeniality on the other. The ascendency component emerged from the competitive nature of examinations and the individual differences between students in ability and effort. The strain to rapport emerged as a norm of courtesy expressed by many students wherein they help each other to save face. In effect, in situations where there are marked status differences as well as a community of congeniality there will be a high degree of impression management.

Once again, what began as a field of study in which data were collected and classified resulted perhaps in another modest extension to existing theory. First Goffman's (1959) forms of impression management were extended (and perhaps enlarged). Second, the theoretical (but never empirically demonstrated) possible outcomes of one of Glazer and Strauss' (1981) four 'awareness contexts,' that of 'pretense awareness' is elaborated. Specifically, we showed how pretense (i.e., impression management) is generated and when it is likely to be of high or low intensity. The patterns of impression management by Aces and Bombers to reveal or conceal accomplishment or failure is also widespread in the work 
world where people compete for jobs, honors, and awards, for example, when academic authors receive acceptances or rejections of submitted articles and perform little dramas of joy or indifference at the mail box, particularly when many other colleagues are present!

\section{The Examination as a Dramaturgical Stage}

A fourth study (Albas \& Albas, 1988b) began with a presumption on our part that the latent function of universities in our society is to transmit the values of universalism and individualism. We hypothesized also that the manifest function of the institution in its examination procedures is to assure scrupulous honesty (not cheating) and maximum achievement. Because of the highly ritualistic, formal and solemn conduct of exams at universities it was decided that the paradigm of dramaturgy developed by Goffman would be a useful framework for understanding how the institution (i.e., the actor) conveyed its messages to the students (i.e., the audience) via the use of 'spaces,' 'props,' 'equipment,' and 'bodies' - all with specific social meanings like seriousness, high thought, individualism, honesty, ordered formality, and bureaucratic aplomb. To demonstrate this we employed the conceptualization and terminology of dramaturgy. Specifically, we pointed out what in the exam setting constitutes spaces, props, equipment and bodies and how these are used to convey the university's message. The data were largely our own observations of exam settings and their conduct over the past fifteen years as well as interviews with university administrators, other professors and invigilators.

On the basis of observations and interviews, we concluded that indeed the large halls in which final exams occur, the placement of the desks with partitions between them (or having greater than usual distances between writers) to prevent copying, the specifically printed examination booklets for answers (which have on their covers elaborate formal instructions as well as a flap to place over the candidate's name to ensure anonymity) plus the presence of vigilant invigilators all conspired to send the message intended by the university which is regarded as the actor in this drama. The serendipitous finding also emerged that the examination act is, for the university actor, a 'rhetoric of idealization' in that the exaggerated emphasis on the show of fairness and equality in 
reality masks a situation less than perfect in regard to these virtues. For example, exams vary in difficulty and content from section to section of a course, and from year to year, and different instructors employ different standards of grading. Consequently, this emphasis on the show of fairness and equality may suggest, as in the case of Lady Macbeth, that the institution might be protesting too much, and wherever there is overprotest one searches for a sense of guilt and for attempts to cover it. Another example can be found in the institutional staging of courtrooms.

\section{Examination Candidates as Players in the Drama}

In the fifth study, (Albas \& Albas, 1988b) which is a companion to the fourth one described above, we investigated the effect upon students writing examinations of the dramaturgical messages the institution endeavors to send by its staging of the examination act. The staging process is characterized as being functional if the responses elicited from students as to the effect of the staging on them corresponded to the intended messages. The staging was categorized as being dysfunctional in cases where student responses seemed either alien from or inimical to the intended message. Each student response was regarded as a 'definition of the situation' for that particular respondent. We used a form of W.I. Thomas' concept refined by Perinbanayagam (1974) in which the definition of the situation is understood as a synthesis of the message sent and the (possibly clashing) interpretation of the message by the receiver. This interpretation is modified by influences both internal and external to the receiver.

The data for this study were drawn mainly from the examination logs provided by students supplemented by probing interviews with them as well as from our own observations. The data were then arranged in the schematic table (Table 2).

From the table it is clear that in most cases students' interpretation and reactions are congruent with the messages sent by the institution. Thus we concluded that for the most part the dramaturgical messagesending was functional and effective. However, there were cases where students' interpretations and reactions differed from the intended messages of the university. For example, sometimes students legitimated the 
Table 2

Schematic representation of student response to institutional messages in the staging of examinations

\begin{tabular}{|c|c|c|c|c|}
\hline MEDIA & \multicolumn{2}{|c|}{ MESSAGE } & \multicolumn{2}{|c|}{ RESPONSE } \\
\hline & Value & Norm & $\begin{array}{l}\text { Interpretation } \\
\text { through verbal } \\
\text { accounts }\end{array}$ & $\begin{array}{c}\text { Overt } \\
\text { Behaviour }\end{array}$ \\
\hline $\begin{array}{l}\text { Space } \\
\text { Auditorium } \\
\text { Great Halls }\end{array}$ & $\begin{array}{l}\text { Achievement } \\
\text { Bureaucracy }\end{array}$ & $\begin{array}{l}\text { Effort } \\
\text { Silence \& } \\
\text { sobriety }\end{array}$ & $\begin{array}{l}\frac{\text { Functional }}{\text { Exaltation }} \\
\text { Exhilaration } \\
\text { Competition } \\
\text { Dysfunctional } \\
\text { Belittlement } \\
\text { Inhibiting }\end{array}$ & $\begin{array}{l}\text { Circumspection } \\
\text { Supression of } \\
\text { spontaneous urges }\end{array}$ \\
\hline $\begin{array}{l}\text { Props } \\
\text { Desks } \\
\text { Dividers } \\
\text { Rows }\end{array}$ & $\begin{array}{l}\text { Individualism } \\
\text { Asceticism } \\
\text { Order }\end{array}$ & $\begin{array}{l}\text { Eyes front } \\
\text { No levity } \\
\text { No wandering }\end{array}$ & $\begin{array}{l}\frac{\text { Functional }}{\text { Discipline }} \\
\text { Straightness } \\
\text { Constriction } \\
\text { Dysfunctional } \\
\text { Over conformity }\end{array}$ & $\begin{array}{l}\text { Attempts to drama- } \\
\text { tize conformity } \\
\text { Challenges }\end{array}$ \\
\hline $\begin{array}{l}\text { Equipment } \\
\text { Exam books \& } \\
\text { instructions } \\
\text { Stickers } \\
\text { I.D. Card }\end{array}$ & $\begin{array}{l}\text { Assurance and } \\
\text { verification of } \\
\text { fairness and } \\
\text { justice }\end{array}$ & $\begin{array}{l}\text { Bring \& show } \\
\text { credentials }\end{array}$ & $\begin{array}{l}\frac{\text { Functional }}{\text { Validity of red }} \\
\text { tape }\end{array}$ & $\begin{array}{l}\text { Exaggerated } \\
\text { caution re: hands, } \\
\text { legs, and trunk } \\
\text { Disappointment } \\
\text { at anonymity \& } \\
\text { attempt to circumvent }\end{array}$ \\
\hline $\begin{array}{l}\text { Bodies } \\
\text { Invigilators }\end{array}$ & $\begin{array}{l}\text { Validity of } \\
\text { procedure }\end{array}$ & Respect & $\begin{array}{l}\text { Functional } \\
\text { Increased sense } \\
\text { of professor's } \\
\text { status } \\
\text { Perception of } \\
\text { police role } \\
\text { Dysfunctional } \\
\text { Inhibition of } \\
\text { thinking }\end{array}$ & $\begin{array}{l}\text { Attempts to foil } \\
\text { over-surveillance }\end{array}$ \\
\hline
\end{tabular}


perceived status and police role of invigilators while in other cases, even though the students' interpretations of the messages were as the institutions intended, their reactions were somewhat deviant and challenging. For example:

On occasion I have stuck my foot out across the aisle so that I can assume a more comfortable (body) position. It also serves to reduce the surveillance aspect of the exam because it prevents invigilators from walking up and down that aisle.

On one occasion I purposely started to stare at a point under the table. As I expected, an invigilator was behind me, just like a hawk. When she saw that I was not cheating she walked away and remained at the other end of the room for the duration of the exam. I often look around me; sometimes I catch a friend's eyes and we nod to each other. I refuse to cease being a human being just because I'm writing an exam. Anybody who really wants to cheat can do it, in spite of all the song and dance (of invigilators).

In sum, in this study we hypothesized that the dramaturgical message of the university would be read correctly and complied with by students. The data largely supported these hypotheses but some aberrations did emerge. Further pursuit and closer examination of them resulted in a refinement of the theory. Specifically, we employed Perinbanayagam's (1974) modification of Thomas' definition of the situation as being a 'rivalry' between the sender's message and the receiver's subjective interpretation of it.

\section{Disclaimer Mannerisms}

In addition, we also attempted to add to symbolic interactionist theory. To show how this occurred it is necessary to provide a brief history. In 1940 C.W. Mills employed the term 'motive-talk' to describe the rationalizations people use to explain their behavior to others and to themselves. In the 1960s Scott and Lyman introduced the term 'accounts' (including excuses and justifications) as an elaboration and refinement of motive talk. In the 1970s Stokes and Hewitt further differentiated 
excuses and justifications into disclaimers (occurring before the act) and accounts (occurring after the act). In effect, the distinction was chronological. No explicit distinction was made between verbal and nonverbal as to the accounts and disclaimers and the implication was that both were verbal. Specifically, their definition of disclaimer was "a verbal device employed to ward off and defeat in advance doubts and negative typifications which may result from intended conduct" (Hewitt \& Stokes, 1975, p. 3).

In the fifth study, that of students as players in the examination drama, we discovered that they employed disclaimers prior to and during exams to demonstrate innocence before they were challenged and in order to avoid being challenged. Because examination rules precluded verbal proclamation, disclaimers were dramatically acted out, that is, they were nonverbal. For example, one student states: "Occasionally I need to look away from my paper. When I do I'm always afraid the prof will think I'm cheating. To show I'm not I look at the ceiling or at the prof." In order to identify student behavior and still maintain the terminology established in the literature (i.e., confining the term disclaimer to verbal behavior) we employed the term 'disclaimer mannerisms' (Albas $\&$ Albas, 1993). In essence, because of the bifurcation and elaboration in the literature of verbal versus nonverbal behavior it seems necessary to show respect for the boundary between them through terminology. Certainly one of the next tasks for research is the investigation and identification through terminology of nonverbal accounts.

\section{Conclusions and Implications of the Study}

The point made at the outset of this paper is that methodology and theory are inseparable components of any scientific strategy to understand and explain. We feel that we have demonstrated the reciprocal process of asking a question, suggesting a theoretical answer, generating relevant empirical data, answering the question and perhaps modifying or extending the theoretical framework within which the question was generated. As we attempted to demonstrate, this process does not always follow the same order of procedures. Quite often data are collected in some particular 
area of interest without clear cut theoretical directions as to the appropriate questions to ask. However, by dint of classification, the observation of patterns and relationships, as well as an awareness of the literature, theoretical sense emerges from what began as seemingly inexplicable facts. These methodological procedures and the inferences made from them concern the field of higher education and, it is hoped, add some light to the focal question concerning the actual dynamics of student study and grade-getting. Our findings along with what is already known about social class and grade-getting as well as grade performance and life chances should contribute to a more comprehensive picture of the educational panorama.

In spite of many criticisms of the examination as an educational procedure (Broadfoot, 1984, 1984; Dale \& Pires, 1984; Hammersley \& Scarth, 1990; Scarth, 1984; Turner, 1984), in view of the fact that nations like China temporarily abolished examinations but found it necessary to restore them (Kwong, 1983) it is clear that exams in some form will always be with us (Broadfoot, 1984, p. 1; Eggleston, 1984, p. 32; Kerchoff, 1995, p. 491; Scarth, 1984, p. 98). Therefore exams seem a suitable and significant focus of attention.

It is true that the findings on examinations at one university might not be perfectly generalizable to all institutions, for example, community colleges. Clearly, these generalizations are not based on probability theory but rather are more in the order of explanatory theory built on the application of concepts developed in one area to another area. We do, however, have evidence from correspondence with a colleague at one elite university of findings similar to ours (Regan, private correspondence). In any case, it is probably fair to suggest that the implications which emerge from this study concerning student stress, emotion work, the value of dramaturgy and the need for expression management are widely applicable. These implications really provide bridges between what would otherwise be isolated examples of reality and thus constitute a degree of generalizaton (Strauss \& Corbin, 1990). In more detail, the implications are as follows: First, it is clear from the studies on magic and emotion work that exams are highly stressful events for students and are coped with in a variety of ways. Educators might legitimately raise 
the question as to whether this stressfulness is positive for the educational function. One thing we do know is that anxiety (stress) has the positive function of encouraging procrastinators to begin studying (Albas \& Albas, 1984). For example, many students indicated that they put off studying until the date for the exam gets so close that they can no longer tolerate the anxiety. In addition, people like Selye (1956) advocate a certain optimum level of stress for effective living in general. Thus, if educators carefully design exams in such a fashion as to achieve this optimum, for example, by giving sufficient notice before the event and making certain that the questions are clearly worded, then exams may be a useful tool to test at least one dimension of students' knowledge. Second, the fourth study on the dramaturgical staging of exams indicates that dramatization has the value of reinforcing such norms as individualism, fairness, industry and integrity which have been traditionally transmitted verbally and, at that level, have not always been fully internalized by students.

The fifth study of student response to the institutional staging of examinations indicates that students understand the objectives of institutional staging and for the most part comply with them. The implications of studies 4 and 5 then, are that the elaborate panoply of ceremony surrounding examinations has more than merely historical or nostalgic value and should be kept. Obviously every institution has its own staging techniques, some more elaborate than others. However, it appears that some amount of dramatization is functional for every exam act. For example, a symmetrical arrangement of desks may well help to induce symbolically orderly thinking. It also acts as a constraint to cheating. As one student states "the straightness of the rows suggests 'no crooked stuff here"". Also, leaving unessential items at the door or at the side of the room may well reduce the temptation to cheat. One student explains it this way "when you can't answer a question but you know where to find the answer in your book and it's right close there (close by)...there's an almost irresistible temptation to open it." Another implication from the study on institutional staging which gains support in a recent study on cheating (Albas \& Albas, in progress) is that an atmosphere of serious solemnity is a deterrent to cheating and that its absence is conducive to it. Thus it is probably a good idea 
to insist on absolute quiet from the time that instructions are issued at the beginning right through until the last papers have been handed in. A final implication of the study on the staging of examinations is that handing out papers face down and having everyone turn them over at the same time dramatizes the norm of universalism. That is, all students have exactly the same amount of time to complete the questions. It is not infrequent that students complain that others who receive their papers first may gain unfair time advantage, especially if the class is large and it takes a long time to distribute the exams. As one student states: "It may just be paranoia on my part but I feel that those at the front consistently get an unfair time advantage over us at the back." Thus, even in cases where exams occur in the regular classroom, the measures suggested above make for a transformation of that classroom into an examination hall with all of its mystique and ceremonial expectations.

One clear implication of the third study of impression management is that the rich (Aces) get richer and the poor (Bombers) get poorer as a result of the post exam interaction within and between the respective groups. In effect, the Aces continue to educate themselves and reach higher levels of academic excellence while the Bombers fall into self-commiserating orgies and often, eventually fall by the wayside. The Bombers need clear encouragement in spite of what is an easier and perhaps almost natural inclination to favor the already favored. This last point is very important because studies (Bean \& Kuh, 1984) indicate that Bombers are not kinds of students most likely to seek help from teachers. Those who do tend to be the extroverted and able students. Also, Pascarella and Terenzini (1979) state that students who interact with teachers are most likely to persevere and complete the course, certainly a notable point in this time of shrinking student enrollments and increased desire on the part of institutions to have as many students as possible graduate. In addition, there are numerous applications beyond the arena of education for the concepts and relationships detailed in this study. For example, in this present period of financial uncertainty, hard nosed investors are consulting psychics and tapping 'magical' knowledge. Also, interviews with employees of a national clothing store chain reveal that they fall into the categories we defined as 
Aces and Bombers with the identical characteristics of mutual emotional support, ambition, and self-assurance.

In sum, we began this article with an invitation to authors to engage in ethnographic study. We are hopeful that the specific studies of university examinations we described provoke this interest and provide a groundwork for future exploration.

\section{References}

Adler, P., \& Adler, P. (1994). Observational techniques. In N. Denzin \& Y. Lincoln (Eds.), Handbook of qualitative research, (pp. 377-392). Thousand Oaks: Sage.

Albas, C., \& Albas, D. (1988). Emotion work and emotion rules: The case of exams. Qualitative Sociology, 11(4), 259-274.

Albas, C., \& Albas, D. (1994). Studying students studying: Perspectives identities, and activities. In M.L. Dietz, R. Prus, \& W. Shaffir (Eds.), Doing everyday life: Ethnography as human experience, (pp. 273-289). Mississauga: Copp Clark Longman.

Albas, D., \& Albas, C. (1984). Student life and exams: Stresses and coping strategies. Dubuque, IA: Kendall/Hunt.

Albas, D., \& Albas, C. (1988a). Aces and bombers: The post-exam impression management strategies of students. Symbolic Interaction, 11(2), 289-302. Reprinted in G. Fine (Ed.), Sociological slices: Interactional readings from an interactionist perspective. New York: JAI Press.

Albas, D., \& Albas, C. (1988b). The institutional staging of an examination."The Canadian Journal of Higher Education, XVIII(1),65-74.

Albas, D., \& Albas, C. (1989a). Modern magic: The case of exams. The Sociological Quarterly, 30(4): 603-613. Reprinted in A. Himmelfarb \& J. Richardson (Eds.), (1992). Sociology for Canadians: A reader, second edition. Toronto: McGraw-Hill Ryerson.

Albas, D., \& Albas, C. (1989b). The staging of examinations: A student response to the institutional perspective. Canadian Journal of Higher Education, XVIII(3), 69-81.

Albas, D., \& Albas, C. (1993). Disclaimer mannerisms of students: How to avoid being labelled as cheaters. Canadian Review of Sociology and Anthropology, 30(4), 451-467. 
Albas, D., \& Albas, C. (in progress). Cheating on university examinations: Strategies and rationales.

Bajema, C., (1968). Interrelations among intellectual ability, educational attainment, and occupational achievement. Sociology of Education, 41, 317-319.

Bean, J.P., \& Kuh, G.D. (1984). The reciprocity between student-faculty informal contact and academic performance of university undergraduate students. Research in Higher Education, 2I(4), 461-477.

Becker, H., \& Geer, B. (1957). Participant observation and interviewing: A comparison. Human Organization, 16, 28-32.

Broadfoot, P. (1984). Assessment, schools and society. London: Methuen.

Burgess, R. (1984). In the field: An introduction to field research. London: George Allen and Unwin.

Cahill, S., Fine, G.A., \& Grant, L. (1995). Dimensions of qualitative research. In K.S. Cook, G.A. Fine, \& J.S. House (Eds.), Sociological perspectives on social psychology, (pp. 605-628). Toronto: Allyn \& Bacon.

Dale, R., \& Pires, E.L. (1984). Linking people and jobs: The indeterminate place of educational credentials. In P. Broadfoot (Ed.), Selection certification and control: Social issues in educational assessment, (pp. 5165). New York: The Falmer Press.

Deutcher, I. (1973). What we say / What we do: Sentiments and acts. Glenview, IL: Scott, Foresman and Company.

Eggleston (1984). In P. Broadfoot (Ed.), Selection, certification and control: Social issues in educational assessment. New York, NY: Falmer Press.

Fine, G., \& Kleiman, S. (1979). Rethinking subculture: An interactionist analysis. American Journal of Sociology, 85, 1-21.

Garfinkel, H. (1967). Studies in ethnomethodology. Englewood Cliffs, NJ: Prentice Hall.

Giddens, A. (1973). The class structure of advanced societies. London: Hutchinson.

Glazer, B., \& Strauss, A. (1981). Awareness contexts and social interaction. In G. Stone \& H. Farberman (Eds.), Social psychology through symbolic interaction, 2nd ed., (pp. 53-63). New York: Wiley.

Gmelch, G. (1971). Baseball magic. Society, 8(8), 39-41.

Goffman, E. (1959). The presentation of self in everyday life. Garden City, NJ: Doubleday Anchor. 
Hammersley, M., \& Scarth, J. (1990). Examinations and teaching: An exploratory study (with John Scarth). In M. Hammersley (Ed.), Classroom ethnology, (pp. 73-90). Open University Press and OISE.

Hewitt, J., \& Stokes, R. (1975). Disclaimers. American Sociological Review, $X L(\mathrm{Feb}), 11$.

Hochschild, A. (1979). Emotion work, feeling rules, and social structure. American Journal of Sociology, 35, 551-573.

Huberman, A.M., \& Miles, M.B. (1983). Drawing valid meaning from qualitative data: Some techniques of data reduction and display. Quality and Quantity, 17(4), 281-339.

Katz, J. (1994). Jazz in social interaction: Personal creativity, collective constraint, and motivational explanation in the social thought of Howard S. Becker. Symbolic Interaction, 17(3), 253-279.

Kuh, G., \& Andreas, R. (1991). It's about time: Using qualitative methods in student life studies. Journal of College Student Development, 32(5), 397-405.

Kerchoff, A.C. (1995). Social stratification and mobility processes: Interaction between individuals and social structures. In K.S. Cook, G.A. Fine, \& J.S. House (Eds.), Sociological perspectives on social psychology, (pp. 477-496). Toronto: Allyn \& Bacon.

Kwong, J. (1983). Is everyone equal before the system of grades: Social background and opportunities in China. The British Journal of Sociology, 34(1), 93-108.

Malinowski, B. (1954). Magic, science, and religion. New York: Doubleday.

Merton, R. (1957). Social theory and social structure (rev. \& enl. ed.). New York: Free Press of Glencoe.

Mills, C.W. (1940). Situated actions and vocabularies of motive. American Sociological Review, V(Oct.), 904-913.

Perinbanayagam, R. (1974). The definition of the situation and the analysis of the ethnomethodological and dramaturgical view. Sociological Quarterly, $15,521-542$.

Pascarella, E.T., \& Terenzini, P.T. (1979). Interaction effects in Spady's and Tinto's conceptual models of college dropout. Sociology of Education, 52(4), 197-210.

Pascarella, E.T., \& Terenzini, P.T. (1991). How college affects students: Findings and insights from twenty years of research. San Francisco: Jossey Bass.

Scarth, J. (1984). Teachers attitudes to examining: A case study. In P. Broadfoot (Ed.), Selection certification and control: Social issues in educational assessment, (pp. 83-102). New York: Falmer Press. 
Scott, M., \& Lyman, S. (1968). Accounts. American Sociological Review, $X X X I I I($ Feb. $), 46-62$.

Selye, H. (1956). The stress of life. New York: McGraw-Hill.

Sexton, P. (1961). Education and income. New York: Viking Press.

Shaffir, W., Stebbins, R., \& Turowetz, J. (eds.) (1981). Fieldwork experience. New York: St. Martin's Press.

Stouffer, S., Lumsdaine, A., Lumsdaine, M., Williams Jr., R., Smith, M., Janise, I., \& Cottrell Jr., L. (1949). Studies in social psychology in World War II: The American solider, combat and its aftermath. Princeton, NJ: Princeton University Press.

Strauss, A., \& Corbin, J. (1990). Basics of qualitative research. Newbury Park, CA: Sage Publications.

Strauss, A., \& Corbin, J. (1994). Grounded theory methodology: An overview. In N. Denzin \& Y. Lincoln (Eds.), Handbook of qualitative research, (pp. 273-285). Thousand Oaks: Sage.

Tepperman, L., \& Curtis, R. (1995). Everyday life: A reader (2nd ed., complete version). Toronto: McGraw Hill, Inc.

Thomas, W.I., \& Zaniecki, F. (1917). The Polish peasant in Europe and America. New York: Octagon Books.

Turner, G. (1984). Assessment in the comprehensive school: What criteria count? In P. Broadfoot (Ed.), Selection certification and control: Social issues in education assessment, (pp. 67-82). New York: The Falmer Press.

Webb, E., Schwartz, R., \& Sechrest, L. (1966). Unobtrusive measures: nonreactive research in the social sciences. Chicago: Rand McNally.

Weber, M. (1968). Economy and society. New York: Bedminister Press.

Wilson, W. (1942). Miners' superstitions. Life and Letters Today, 32, 86-93.

Yin, R. (1994). Case study research: Design and methods (2nd ed.). Thousand Oaks: Sage. 